\title{
Front Matter: Volume 6851
}

, "Front Matter: Volume 6851," Proc. SPIE 6851, Endoscopic Microscopy III, 685101 (26 February 2008); doi: 10.1117/12.791302

SPIE. Event: SPIE BiOS, 2008, San Jose, California, United States 


\section{PROGRESS IN BIOMEDICAL OPTICS AND IMAGING}

Vol. 9, No. 10

\section{Endoscopic Microscopy III}

Guillermo J. Tearney

Thomas D. Wang

Editors

20-21 January 2008

San Jose, California, USA

Sponsored and Published by

SPIE

Volume 6851 
The papers included in this volume were part of the technical conference cited on the cover and title page. Papers were selected and subject to review by the editors and conference program committee. Some conference presentations may not be available for publication. The papers published in these proceedings reflect the work and thoughts of the authors and are published herein as submitted. The publisher is not responsible for the validity of the information or for any outcomes resulting from reliance thereon.

Please use the following format to cite material from this book:

Author(s), "Title of Paper," in Endoscopic Microscopy III, edited by Guillermo J. Tearney, Thomas D. Wang, Proceedings of SPIE Vol. 6851 (SPIE, Bellingham, WA, 2008) Article CID Number.

ISSN $1605-7422$

ISBN 9780819470263

Published by

SPIE

P.O. Box 10, Bellingham, Washington 98227-0010 USA

Telephone +1 3606763290 (Pacific Time) · Fax +1 3606471445

SPIE.org

Copyright @ 2008, Society of Photo-Optical Instrumentation Engineers.

Copying of material in this book for internal or personal use, or for the internal or personal use of specific clients, beyond the fair use provisions granted by the U.S. Copyright Law is authorized by SPIE subject to payment of copying fees. The Transactional Reporting Service base fee for this volume is $\$ 18.00$ per article (or portion thereof), which should be paid directly to the Copyright Clearance Center (CCC), 222 Rosewood Drive, Danvers, MA 01923. Payment may also be made electronically through CCC Online at copyright.com. Other copying for republication, resale, advertising or promotion, or any form of systematic or multiple reproduction of any material in this book is prohibited except with permission in writing from the publisher. The CCC fee code is 1605$7422 / 08 / \$ 18.00$.

Printed in the United States of America.

Publication of record for individual papers is online in the SPIE Digital Library.

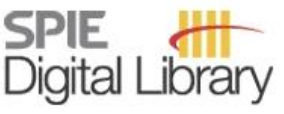

SPIEDigitalLibrary.org

Paper Numbering: Proceedings of SPIE follow an e-First publication model, with papers published first online and then in print and on CD-ROM. Papers are published as they are submitted and meet publication criteria. A unique, consistent, permanent citation identifier (CID) number is assigned to each article at the time of the first publication. Utilization of CIDs allows articles to be fully citable as soon they are published online, and connects the same identifier to all online, print, and electronic versions of the publication. SPIE uses a six-digit CID article numbering system in which:

- The first four digits correspond to the SPIE volume number.

- The last two digits indicate publication order within the volume using a Base 36 numbering system employing both numerals and letters. These two-number sets start with 00, 01, 02, 03, 04, $05,06,07,08,09,0 A, 0 B \ldots$ OZ, followed by 10-1Z, 20-2Z, etc.

The CID number appears on each page of the manuscript. The complete citation is used on the first page, and an abbreviated version on subsequent pages. Numbers in the index correspond to the last two digits of the six-digit CID number. 


\section{Contents}

$\checkmark$ Conference Committee

\section{SESSION 1 CONFOCAL TECHNIQUES}

685103 Clinical evaluation of a confocal microendoscope system for imaging the ovary [6851-02] A. A. Tanbakuchi, College of Optical Sciences, Univ. of Arizona (USA) and Univ. of Arizona (USA); A. R. Rouse, K. D. Hatch, Univ. of Arizona (USA); R. E. Sampliner, Southern Arizona VA Health Care System (USA); J. A. Udovich, A. F. Gmitro, College of Optical Sciences, Univ. of Arizona (USA) and Univ. of Arizona (USA)

685104 In vivo endoscopic autofluorescence microspectro-imaging of bronchi and alveoli [6851-03]

G. Bourg-Heckly, Univ. Pierre et Marie Curie (France); L. Thiberville, Roven Univ. Hospital (France); C. Vever-Bizet, Univ. Pierre et Marie Curie (France); B. Viellerobe, Mauna Kea Technologies (France)

\section{SESSION 2 ENDOSCOPIC OCT}

685107 Laparoscopic optical coherence tomographic imaging of human ovarian cancer [6851-06]

L. P. Hariri, The Univ. of Arizona (USA); G. T. Bonnema, College of Optical Sciences, The Univ. of Arizona (USA); K. Schmidt, K. Hatch, The Univ. of Arizona (USA); M. Brewer, The Univ. of Arizona (USA) and Univ. of Connecticut, Farmington (USA); J. K. Barton, The Univ. of Arizona (USA) and College of Optical Sciences, The Univ. of Arizona (USA)

6851 OA Scatter sensitive microscopic techniques to identify contrasting mucosal structures in ultrahigh-resolution optical coherence tomograms of mouse colon [6851-10]

A. R. Tumlinson, The Univ. of Arizona (USA) and Cardiff Univ. (United Kingdom); L. P. Hariri, The Univ. of Arizona (USA); W. Drexler, Cardiff Univ. (United Kingdom); J. K. Barton, The Univ. of Arizona (USA)

\section{SESSION 3 EMERGING IMAGING TECHNIQUES}

$6851 \mathrm{OB}$ Two-photon imaging using a flexible endoscope [6851-11]

I. Riemann, Fraunhofer Institute of Biomedical Technology (Germany); S. Schenkl, Fraunhofer Institute of Biomedical Technology (Germany) and Saarland Univ. (Germany); R. Le Harzic, Fraunhofer Institute of Biomedical Technology (Germany) and JenLab GmbH (Germany); D. Saver, Fraunhofer Institute of Biomedical Technology (Germany); A. Ehlers, Fraunhofer Institute of Biomedical Technology (Germany) and Saarland Univ. (Germany);

B. Messerschmidt, Grintech GmbH (Germany); R. Bückle, JenLab GmbH (Germany);

K. König, Saarland Univ. (Germany) and JenLab GmbH (Germany) 
6851 OD Miniaturized probe using 2 axis MEMS scanner for endoscopic multiphoton excitation microscopy [6851-13]

W. Jung, Beckman Laser Institute (USA) and Univ. of California, Irvine (USA); S. Tang, Univ. of British Columbia (Canada); T. Xie, Beckman Laser Institute (USA); D. T. McCormick, Advanced MEMS (USA); Y.-C. Ahn, Beckman Laser Institute (USA); J. Su, Beckman Laser Institute (USA) and Univ. of California, Irvine (USA); I. V. Tomov, T. B. Krasieva, Beckman Laser Institute (USA); B. J. Tromberg, Z. Chen, Beckman Laser Institute (USA) and Univ. of California, Irvine (USA)

6851 OF Real-time image mosaicing with a hand-held dual-axes confocal microscope [6851-15] K. Loewke, D. Camarillo, W. Piyawattanametha, D. Breeden, K. Salisbury, Stanford Univ. (USA)

\section{SESSION 4 NOVEL IMAGING APPROACHES}

6851 OG Artifact removal in Fourier-domain OCT with a rotating probe [6851-16]

S. Vergnole, G. Lamouche, M. L. Dufour, B. Gauthier, C. Padioleau, IMI-NRC (Canada)

6851 Ol Endoscopic common-path OCT based on sweeping laser source and curled optical patch cord [6851-18]

J. S. Park, E. J. Jung, M. Y. Jeong, C.-S. Kim, Pusan National Univ. (South Korea); J. U. Kang, Johns Hopkins Univ. (USA)

6851 OK An endoscope for simultaneous macroscopic navigation and microscopic inspection of luminal sidewalls [6851-20]

S. Leavesley, J. Sturgis, J. P. Robinson, Purdue Univ. (USA)

$6851 \mathrm{OL}$ Fluorescent and scattering contrast agents in a mouse model of colorectal cancer [6851-21]

A. M. Winkler, P. F. S. Rice, T. S. Troutman, The Univ. of Arizona (USA); M. V. Backer, J. M. Backer, SibTech, Inc. (USA); R. A. Drezek, Rice Univ. (USA); M. Romanowski,

J. K. Barton, The Univ. of Arizona (USA)

\section{POSTER SESSION}

6851 ON A fluorescence sectioning endoscopy using dynamic speckle illumination [6851-24] J. Yin, Huazhong Univ. of Science and Technology (China) and Shenzhen Univ. (China); Y. Shao, J. Qu, H. Lin, H. Niu, Shenzhen Univ. (China)

Author Index 


\title{
Conference Committee
}

\author{
Symposium Chairs \\ James G. Fujimoto, Massachusetts Institute of Technology (USA) \\ R. Rox Anderson, Wellman Center for Photomedicine, Massachusetts \\ General Hospital (USA), and Harvard School of Medicine (USA) \\ Program Track Chairs \\ Tuan Vo-Dinh, Duke University (USA) \\ Anita Mahadevan-Jansen, Vanderbilt University (USA) \\ Conference Chairs
}

Guillermo J. Tearney, Massachusetts General Hospital (USA)

Thomas D. Wang, University of Michigan (USA)

Program Committee

Arthur F. Gmitro, The University of Arizona (USA)

Martin R. Harris, OptiScan Pty. Ltd. (Australia)

Ralf Kiesslich, Johannes Gutenberg Universität Mainz (Germany)

François Lacombe, Mauna Kea Technologies (France)

Stephen Lam, British Columbia Cancer Agency (Canada)

Hiroshi Mashimo, Harvard Medical School (USA)

Kenzi Murakami, Olympus Corporation (Japan)

Norman S. Nishioka, Massachusetts General Hospital (USA)

Mark J. Schnitzer, Stanford University (USA)

Peter T. C. So, Massachusetts Institute of Technology (USA)

Session Chairs

1 Confocal Techniques

Guillermo J. Tearney, Massachusetts General Hospital (USA)

2 Endoscopic OCT

Thomas D. Wang, University of Michigan (USA)

3 Emerging Imaging Techniques

Arthur F. Gmitro, The University of Arizona (USA) 
$4 \quad$ Novel Imaging Approaches

Stephen Lam, The BC Cancer Research Center (Canada)

Poster Session

Thomas D. Wang, University of Michigan (USA)

Guillermo J. Tearney, Massachusetts General Hospital (USA) 